
ПІДГОТОВКА ВИКЛАДАЧІВ ДО ОРГАНІЗАЦІЇ САМОСТІЙНОЇ РОБОТИ
В ЗАКЛАДАХ ВИЩОЇ ОСВІТИ УКРАЇНИ ЯК ПЕДАГОГІЧНА ПРОБЛЕМА

\title{
PREPARING TEACHERS FOR ORGANIZATION OF INDEPENDENT WORK IN HIGHER EDUCATION IN UKRAINE AS A PEDAGOGICAL PROBLEM
}

У статті розглянуто стан організації самостійної роботи студентів у період переходу України до нової моделі системи вищої освіти, підходи до якої потребують докорінних змін. Сучасні суспільно-економічні та політичні умови вимагають від майбутніх спеціалістів глибоких і міцних знань зі спеціальності, вдосконалення вмінь і навичок, як не можна отримати тільки на лекційних і практичних заняттях. Необхідність засвоєння великої кількості необхідної інформації студентами закладів вищої освіти актуалізує потребу вдосконалення самостійної роботи студентів як засобу підвищення ефективності навчання та якості підготовки молодого спеціаліста. Згідно з кредитно-модульною системою, здатність до самостійного навчання є необхідним складником загальної компетенції студента. До пріоритетів освіти, що орієнтуються на сучасний ринок праці, зараховують уміння оперувати такими знаннями й технологіями, які здатні задовольнити потреби інформаційного суспільства, підготувати студентів до нових ролей у цьому суспільстві. Сьогодні дуже важливо вміти не лише оперувати власними знаннями, а й бути готовими змінюватися та пристосовуватися до нових потреб ринку праці, вміти управляти інфрормацією, швидко приймати рішення та активно діяти, навчаючись упродовж свого життя.

Сучасна вища педагогічна освіта вимагає інноваційних підходів до організації самостійної роботи студентів. Це зумовлено інфрормацією суспільства загалом, а також вимогами до навчально-виховного прочесу у вищій школі, пов'язаними з інтеграцією України до європейського освітнього простору. Звичайно, проблема організації самостійної роботи студентів не нова. Теорія та методика навчання у вищий школі має деякий арсенал наукових досліджень, які аналізують той чи інший аспект самостійної роботи студентів, але як сама практика їі організації, так і дидактика ще далекі від ефективного розв'язання завдань професійноі підготовки майбутніх спеціалістів. У вищих навчальних закладах виникає необхідність якісно нового рівня організації самостійної роботи студентів, який урахував би попередній досвід та останні наукові дослідження в галузі педагогіки.

здійснено дослідження щодо пізнавальної діяльності студентів і ї залежності від уміння організовувати самостійну роботу. Вивчено, за допомогою яких форм і методів викладач може ефективно управляти нею та контролювати їі в процесі навчання. Проаналізовано ефрективні фрорми самостійної роботи студентів. На основі опрацювання, узагальнення й систематизації наукової літератури виділено фрактори, які сприяють підвищенню активності до самостійної роботи студентів закладів вищої освіти. Визначено шляхи стосовно поліпшення організації та методичного супроводу самостійної роботи студентів, адже самостійна робота полягає в самомоти- вації студентів. Але, щоб стимулювати ї в студентів, потрібно встановити сильну взаємодію між викладачем і студентом, що стає невід'ємним компонентом сучасної вищої освіти.

Ключові слова: самостійна робота, самоосвіта, самореалізація, самовдосконалення, форми організації самостійної роботи, пізнавальна активність студентів, управління самостійною роботою студентів, фрактори активізації самостійної роботи.

The state of organization of students' independent work during the transition of Ukraine to the new model of the higher education system, approaches to which require radical changes, is considered. Modern socio-economic and political conditions require future specialists to have deep and solid knowledge in the field of improving skills that can not be obtained only in lectures and practical classes. The need to assimilate a large amount of information required by students of higher education institutions actualizes the need to improve students' independent work as a means of improving the effectiveness of training and quality of training of young specialists. According to the credit-modular system, the ability to self-study is a necessary component of the student's overall competence. Priorities in education that focus on the modern labor market include the ability to operate with such knowledge and technology that can meet the needs of the information society, prepare students for new roles in this society. Today, it is very important to be able to operate not only with your own knowledge, but also to be ready to change and adapt to the new needs of the labor market, to be able to manage information, to make quick decisions and to act proactively, throughout your life.

Modern higher education requires innovative approaches to the organization of students' independent work. This is due to the information of the society as a whole, as well as the requirements for the educational process in higher education, related to the integration of Ukraine into the European educational space. Of course, the problem of organizing students' independent work is not new. Theory and methodology of higher education have some arsenal of scientific research that analyzes one or another aspect of students' independent work, but both the practice of its organization and didactics are still far from effectively solving the tasks of professional training of future specialists. Higher education institutions need a new level of organization of independent work of students, which would take into account previous experience and recent scientific research in the field of pedagogy.

Research has been carried out on students cognitive activity and its dependence on the ability to organize independent work. It explores what forms and methods the teacher can effectively manage and control in the learning process. Effective forms of students independent work are analyzed. On the basis of elaboration, generalization and systematization of scientific literature, the factors that contribute to increasing the activity of independent 
students of higher education institutions are highlighted. The ways of improving the organization and methodical support of students independent work are determined. After all, independent work consists in self-motivation of students. But in order to stimulate it for students it is necessary to establish a strong interaction between the teacher and the stu- dent, which becomes an integral component of modern higher education.

Key words: independent work, self-education, self-realization, self-improvement, forms of organization of independent work, cognitive activity of students, management of independent work of students, factors of activation of independent work
Постановка проблеми в загальному вигляді. На сучасному ринку праці фрахівець уважається конкурентоспроможним тільки тоді, коли має здатність самостійно приймати рішення в нестандартних ситуаціях, рухатися індивідуальними шляхами самовдосконалення, власними зусиллями збагачувати сореру професійних знань і вмінь. У зв'язку з цим головним завданням закладів вищої освіти в підготовці майбутніх фрахівців є оволодіння ними ефективними методами самостійної навчальної роботи відповідно до конкретного фаху.

Найбільш актуальною ця проблема виявилася у сорері професійної підготовки педагогічних працівників, оскільки з'явився новий попит на фрахівця, здатного здійснювати педагогічне керівництво за самостійною роботою студентів. Викладач, який має досвід ефективної організації власної самостійної роботи, зможе фрормувати самостійність у своїх вихованців, спроможність до успішної життєдіяльності, що перебуває в динамічному розвитку.

Успішність і якість процесу навчання можна досягти за допомогою правильної організації та контролю самостійної роботи студентів, оскільки такий підхід зосереджений саме на формуванні профресійної компетентності студентів. Успішність самостійної роботи залежить від різноманітних фракторів. До таких фракторів можна зарахувати співпрацю викладача зі студентом, установлення сприятливих умов навчання та індивідуальні здібності студентів. До вищезгаданого варто додати мотивацію, яка $€$ важливим елементом самопідготовки.

Актуальною стала проблема саме раціональної організації самостійної роботи з урахуванням готовності до неї студентів. Беручи до уваги думку В. Корнещук, можемо сказати, що невміння самостійно опрацьовувати матеріал, неспроможність спланувати й організувати власне навчання $€$ певними труднощами студентів першого курсу вишів [2, с. 72].

Аналіз останніх досліджень і публікацій. У теорії та практиці вищої освіти накопичено великий досвід, який можна використати для вдосконалення самостійної роботи майбутніх викладачів: розглянуто теоретико-методологічні основи організації самостійної роботи в системі фахової підготовки педагога в умовах університетської освіти (А. Алексюк, В. Бондар, С. Вітвицька, О. Кучерявий, О. Мещаніков, В. Мороз, Ю. Пімєнова та ін.); визначено педагогічні умови щодо підвищення есрективності організації та керування самостійною роботою студентів (Е. Гапон, М. Смирнова, М. Солдатенко, І. Шимко та ін.); привернуто увагу до самостійної роботи студентів як засобу вдосконалення підготовки майбутнього викладача (І. Бобакова, В. Буринський та ін.); системний підхід в організації самостійної роботи студентів досліджувався в роботах Г. Гнитецької, Л. Заякиної.

На необхідність модернізації самостійної роботи студентів закладів вищої освіти 3 метою поліпшення їхньої професійної підготовки вказували такі педагоги-дослідники: В. Козаков, В. Паламарчук, О. Пєхота, О. Савченко, Т. Шамова, І. Шапошнікова.

Виділення не вирішених раніше частин загальної проблеми. Сучасна вища освіта поступово, але неухильно переходить від передачі знань до керівництва навчально-пізнавальною діяльністю та фрормування в студентів навиків самостійної роботи. Самостійна робота студентів, підходи до якої потребують докорінних змін, на сучасному етапі повинна стати основою вищої освіти.

Зміна концептуальної основи й розширення функцій самостійної роботи студента не тільки призводять до збільшення навантаження, а й вимагають зміни у взаєминах між викладачем i студентом як рівноправними суб'єктами навчальної діяльності й потребують підготовки фрахівців.

Виникає необхідність у коригуванні різними психолого-педагогічними засобами забезпечення самостійної роботи студентів. Значущість самостійної компоненти в навчанні студентів підтверджується тим фрактом, що в значній більшості країн співвідношення часу, яке відводиться на аудиторну й самостійну роботу, становить 1:3,5 [3, с. 20].

Саме самостійна робота забезпечить «набуття комунікативного досвіду, що сприяє розвиткові креативних здібностей студентів і спонукає до самореалізації фрахівців, активізує пізнавальні інтереси, реалізує евристичні здібності як визначальні для фрормування професійної майстерності й конкурентоздатності сучасного фрахівця» [6, с. 647].

Усе це зумовлює пошуки таких фрорм навчальної роботи в закладах вищої освіти (далі - 3ВО), коли допомога й контроль 3 боку викладача не пригнічуватимуть ініціативи студента, а навчатимуть його самостійно вирішувати питання щодо планування, організації та контролю за своєю навчальною діяльністю, виховуючи самостійність, самосвідомість і самореалізацію як особисті риси характеру. 
Мета статті - висвітлити проблеми керування самостійною роботою студентів закладів вищої освіти й визначити шляхи подолання їх у навчальному процесі.

Виклад основного матеріалу. Актуальність дослідження зумовлена, по-перше, розробленням нових навчальних планів, у яких акцент зроблено на скорочення аудиторних годин і розширення кількості часу для самостійної роботи студентів; по-друге, збільшенням кількості студентів, що навчаються за індивідуальним графіком, а це потребує не тільки значної уваги викладачів, а й методичного забезпечення самостійної роботи цих студентів; по-третє, першочерговою потребою студентів ефективно й раціонально організовувати навчально-пізнавальну діяльність, яка потребує наявності в них певних дидактичних умінь: уміння планувати цю роботу, чітко формувати систему завдань, виділяти серед них найголовніші, вміло обирати способи для оптимального вирішення поставлених завдань, здійснювати ефективний постійний контроль за виконанням завдань, уносити необхідні корективи в самостійну роботу, підводити загальні підсумки своєї роботи, порівнювати ці результати з наміченими тактичними та опера- ційними цілями, знаходити причини недоліків і намічати шляхи їх усунення в наступній діяльності.

Отже, завданням дослідження було з'ясування ставлення студентів до самостійної роботи, виявлення форм, змісту цього виду діяльності, визначення її регулярності й організація методичного забезпечення на цьому етапі.

Вирішенню поставлених завдань сприяло дослідження, яке проведене на базі Миколаївського національного аграрного університету у 2019 році. У дослідженні взяли участь 147 студентів 1-3 курсів і 13 викладачів інженерно-енергетичного фракультету. Серед студентів проведено анкетування щодо повноти й ефективності їхньої професійної підготовки в майбутній діяльності. Особливу цінність для дослідження мали питання, що стосуються саме самостійної роботи студентів.

Так, на запитання стосовно форми організації освітнього процесу в ЗВО, що стимулюють інтерес до самостійного оволодіння знаннями, 41,3\% студентів назвали семінари, 30,3\% визначили практичні заняття і 13\% - завдання-комплекси, що пов'язані з основними розділами дисципліни, які видаються на навчальний рік і логічно взаємопов'язані. Так, кожний тематичний комплекс

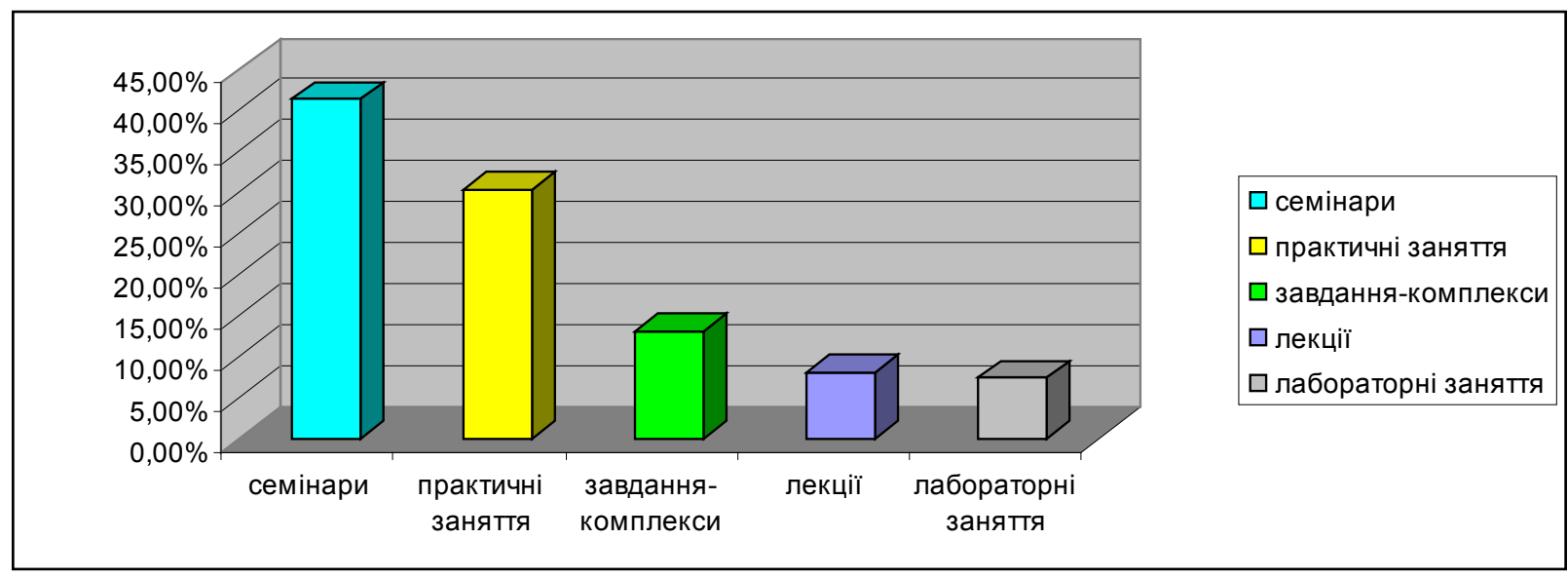

Рис. 1. Форми організації освітнього процесу стосовно стимулювання самостійної роботи

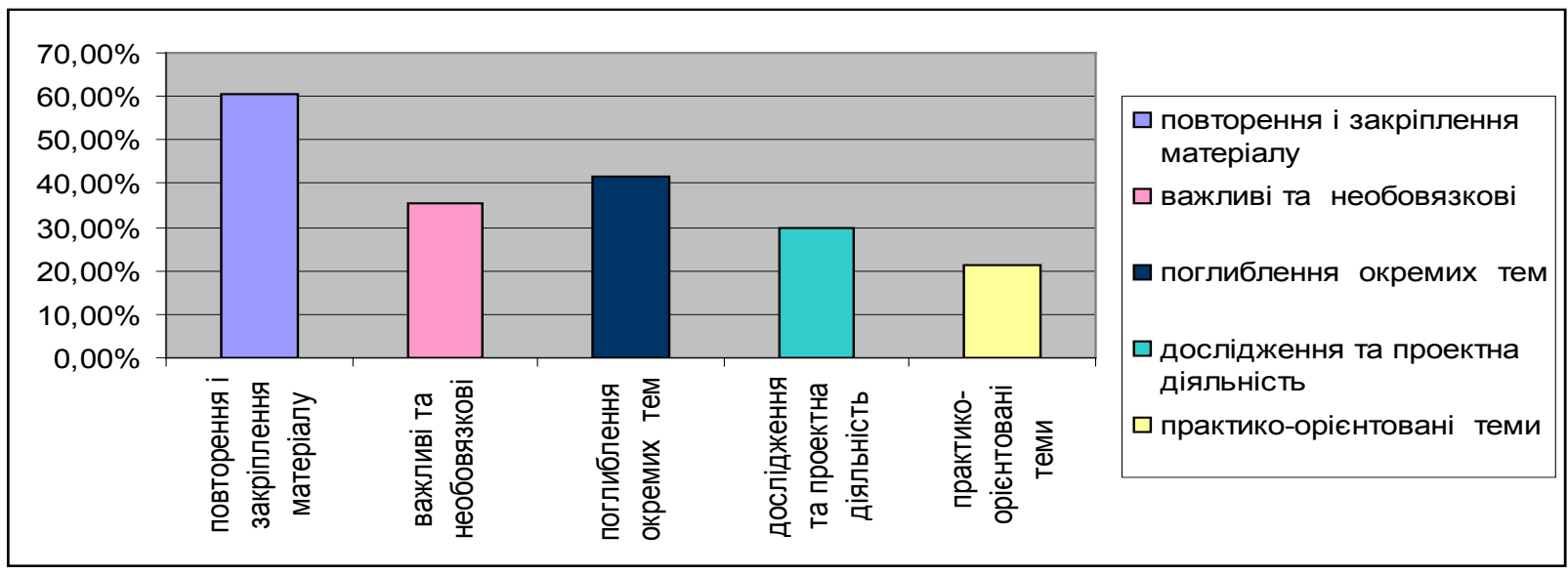

Рис. 2. Рівень зацікавленості студентів самостійною роботою стосовно тем 
може складатися 3 5-7 завдань, а саме: скласти глосарій до теми або опорну схему чи заповнити опорну таблицю; відповісти на питання самоперевірки; розв'язати ситуаційні завдання та вправи. При цьому лекції $(8,1 \%)$ і лабораторні роботи (7,3\%) студенти не вважають стимулом для активізації власної пізнавальної діяльності (рис. 1).

Варто звернути увагу на те, що 70,7\% студентів не вважають виробничу практику простором вияву своєї самостійності.

Результати дослідження дають змогу зробити висновок, що спонукають до самостійної активності студентів такі форми роботи, на яких чітко визначений поетапний контрольно-оціночний компонент. Саме можливість набрати бали більше приваблює студентів, аніж бажання розширити сфреру своїх профресійних знань і вмінь, тоді як лекції з певної дисципліни або лабораторні роботи не спонукають студентів до самостійної навчально-пізнавальної діяльності. А небажання проявити самостійність під час виробничої практики свідчить або про слабкий професійний інтерес студентів, або про надмірне опікування ними викладачів, яке знижує потребу студентів у самостійній підготовці.

Стосовно особливостей тематичної конкретизації самостійної роботи студентів поставлено запитання: «Які ж теми викладачі зобов'язанні виносити на самостійне опрацювання?»

Так як у студентів була змога обрати декілька відповідей водночас, ми одержали такі результати. $60,7 \%$ студентів уважають, що це теми, які орієнтовані на повторення й закріплення вивченого матеріалу. 35,6\% уважають, що це теми, спрямовані на вивчення деяких окремих питань, які не є важливими та обов'язковими, а більше являють собою довідкову інформацію для загального розвитку. 41,7\% студентів, які вказали на матеріал поглиблення окремих тем, а 29,7\% бажають самостійно здійснювати дослідницьку або проектну діяльність під час самостійної роботи, лише 21,5\% студентів назвали практико-орієнтовані теми (рис. 2).

Можна зробити висновок, що більшість студентів розглядають самостійну роботу лише як репродуктивне повторення 3 незначним поглибленням вивченого матеріалу з викладачем, а не стартовий

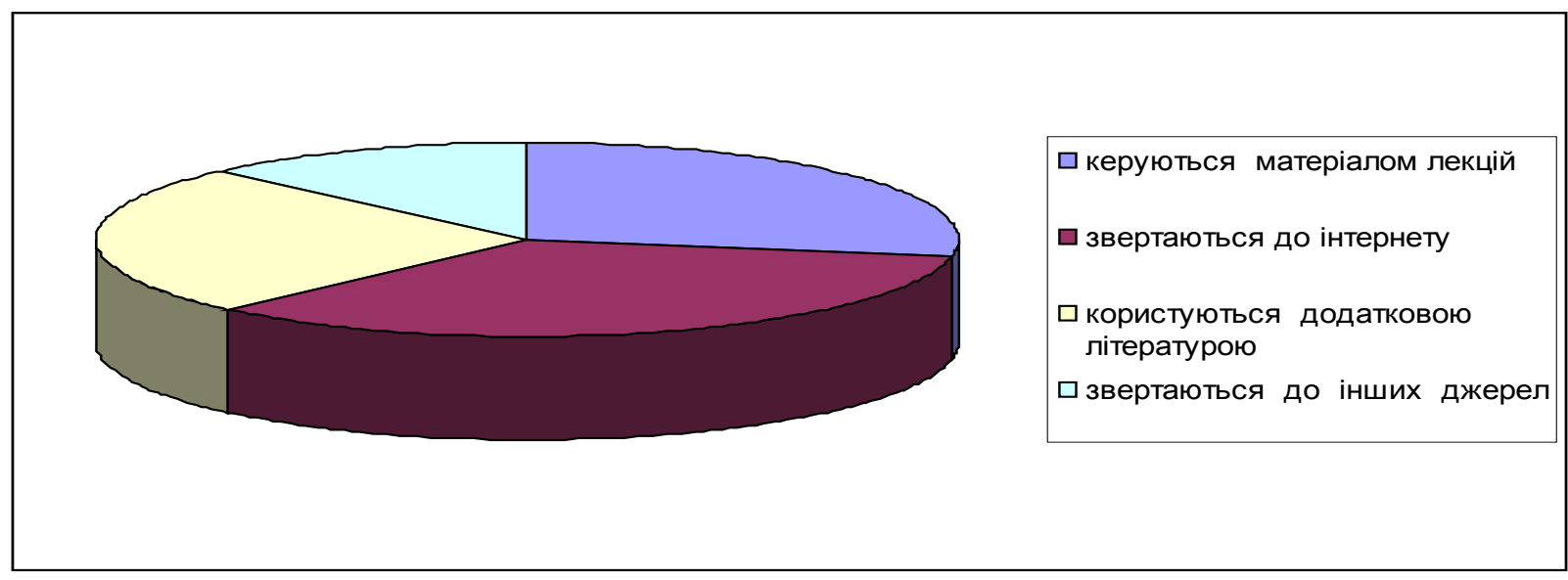

Рис. 3. Співвідношення між використанням засобів до самостійної підготовки

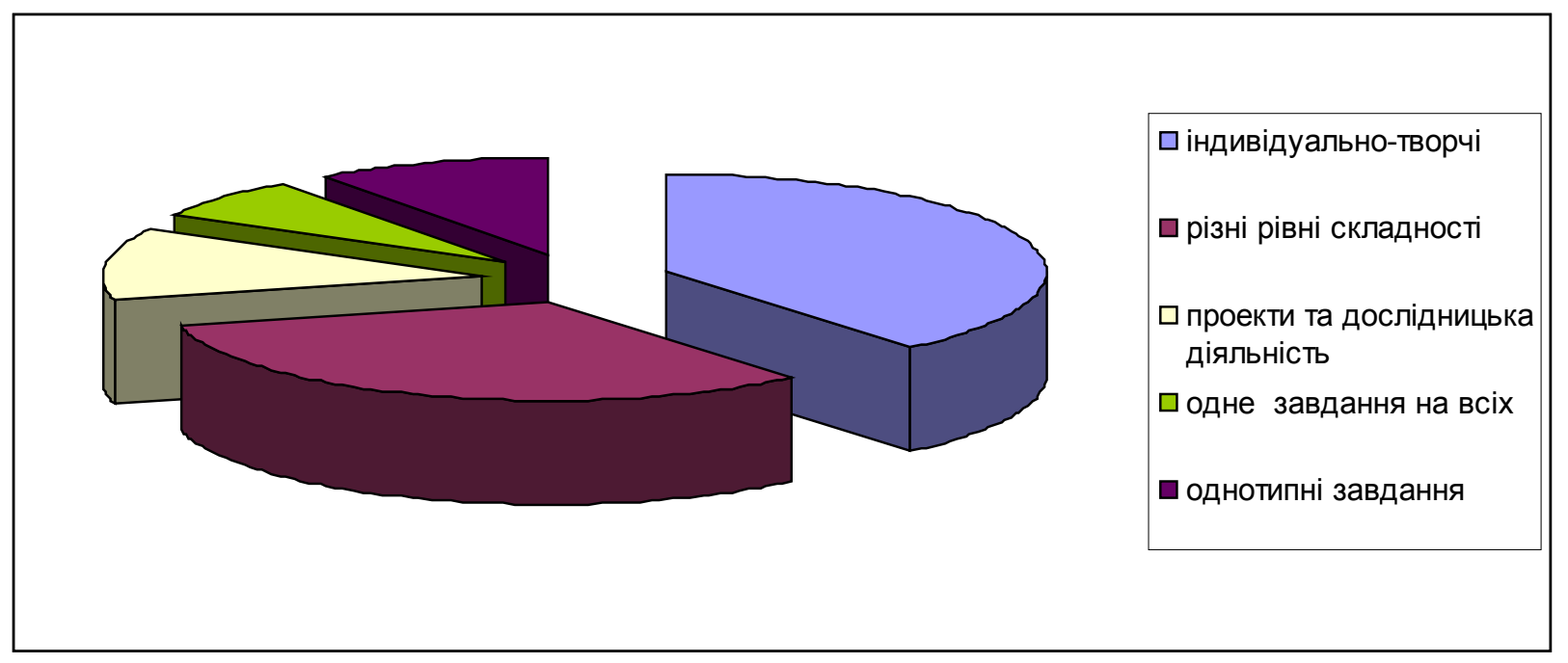

Рис. 4. Співвідношення різновидів самостійних завдань, пропонованих викладачами 
майданчик для подальшого руху в освоєнні професійних знань. I тільки третя частина студентів бажає самостійно відкривати для себе горизонти нових знань, самовдосконалюватися завдяки дослідницькій і проектній діяльності.

Дуже цікаво й те, що 47\% студентів під час самостійної підготовки до занять керуються лише матеріалом лекцій викладачів, 58\% звертаються до інтернет-ресурсів, 43\% використовують додаткову літературу й 21\% залучають інші джерела інорормації (рис. 3).

Це свідчить саме про те, що кожен студент намагається знаходити найбільш зручніші для нього інформаційні джерела, які відповідають його інтересам і вподобанням і $є$ ситуаційно виправдані.

Опитавши викладачів, ми отримали результати, які збігаються 3 результатами відповідей під час анкетування студентів. Більшість студентів знаходить час для консультації з викладачем для кращого опрацювання поданого на лекціях матеріалу. Отже, потреба в консультаціях виникає в 71\% студентів, спілкування з викладачем потребують 63\% для опрацювання пропущеного матеріалу, 47,9\% уточнюють під час консультацій деталі лекційного матеріалу, 35\% мають бажання розв'язувати додаткові та творчі завдання, лише 27,1\% роблять спроби дискутувати 3 викладачем, виявляють свою позицію і намагаються відстоювати їі, використовуючи додаткові аргументи й факти.

Отже, можна стверджувати, що консультації викладачів найчастіше мають репродуктивний характер, який збігається з відповідями студентів щодо змістового наповнення їхньої самостійної роботи.

Одержані дані підтверджені й характером завдань, які пропонувалися викладачами для самостійної роботи: 39\% завдань можна зарахувати до категорії індивідуально-творчих, 32\% охоплюють різні рівні складності, 12\% - проекти й завдання пошуково-дослідного характеру, однотипні завдання становлять 10\%, одне завдання на всіх - 7\% (рис. 4).

Отже, дослідження показало певну відповідність між даними викладачем завданнями й виявленням самостійності в студентів. Важливо відмітити, що після роз'яснення викладачів завдання, яке дається одразу більшості студентів, й однотипні завдання частіше виконуються студентами за єдиним шаблоном. Варто відзначити, що це як значно як позитивний ефект від виконання завдання, так й уповільнює вияв самостійності студентів. Що стосується проектної діяльності, то вона часто залишається поза увагою студентів, бо потребує інтегрованих знань із різноманітних предметів, вміння проводити пошуково-дослідну діяльність та комунікативної компетентності. Крім того, ця діяльність потребує значно більше часу для виконання самостійної роботи, тому це впливає на студентський вибір завдань. Також виконання проектних завдань вимагає й значної підтримки та допомоги викладача, оскільки не всі виконавці проекту можуть бути компетентними щодо особливостей певного виду діяльності.

3'ясовано й кількість часу, яка витрачається студентами на індивідуальну підготовку до занять. Середні показники зводилися до 4,5 години в робочі дні та 5,5 годин у вихідні. Студенти старших курсів витрачають порівняно з першокурсниками менше часу на самостійну роботу.

Стосовно проблем, що пов'язані з організацією самостійної роботи, студенти виділили 2 групи труднощів. До першої вони зарахували досить великий обсяг інорормації та недостатність часу на її опрацювання. Це швидше за все свідчить про невміння студентів розрахувати власний час і раціонально вибудовувати роботу, що, на думку деяких дослідників, є запорукою успіху. В. Петрук уважає, що самостійна робота - це навчання, яке визначає здатність студентів усвідомлено для

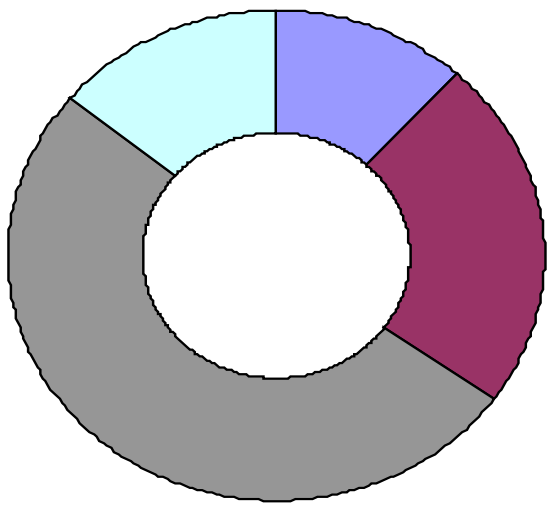

$\square$ необхідна умова

не виключають значення планування

口дуже рідко повязують успіх планування

口успіх залежить від інших причин

Рис. 5. Залежність успіху та позитивного результату від планування навчальної діяльності 
себе ставити завдання, цілі, планувати власну діяльність і здійснювати її [4, с. 23].

Цей висновок підтверджено опитуванням студентів щодо ролі планування в досягненні позитивних результатів та успіхів. На питання «Вважаєте Ви, що планування діяльності є запорукою отримання позитивного результату й успіху роботи?» студенти дали такі відповіді: 11,8\% опитаних уважають, що це $є$ необхідною умовою успіху; 23,2\% не виключають значення щодо планування в досягненні позитивних результатів у роботі; 51,1\% дуже рідко пов'язують успіх із плануванням; а 13,9\% студентів стверджують, що успіх залежить від інших причин, але не від планування (рис. 5).

Одержані результати свідчать, що більшість студентів не вбачає необхідності чітко планувати власну діяльність, бо впевнена, що детально розроблені плани не реалізуються через вплив різноманітних непередбачуваних причин і фракторів.

Друга група труднощів більше пов'язана 3 методичним забезпеченням самостійної роботи студентів викладачами й мала такі причини: нечіткість фрормулювання завдань, відсутність методичних рекомендацій щодо виконання завдань, зависокі вимоги викладачів.

Висновки. Дослідження дало змогу резюмувати таке:

1. Самостійна робота зараз переважно виконує функцію повторення, уточнення та закріплення матеріалу й має нижчий рівень за аудиторну роботу. Викладачі частіше перебільшують роль логічного початку у викладанні своїх дисциплін і не приділяють уваги проблемі сприйняття його студентами. Рідко висвітлюються міждисциплінарні зв'язки, що впливають на краще засвоєння викладеного матеріалу.

2. Немає великої зацікавленості студентів виконанням самостійних завдань, адже вони не бачать їх ролі в профресійному зростанні. Важливим спонукальним чинником $є$ можливість бути успішним і вмотивованим у майбутній професійній діяльності. В. Корнещук стверджує, що успішність самостійної роботи залежить від усвідомлення необхідності професійного зростання. Високий рівень мотивації щодо отримання фрахових знань, фрормування вмінь і навичок сприяють самостійній пізнавальній активності, бажанню досягати успіхів в оволодінні обраною профресією [2, с. 73]. Самостійна робота за зацікавленого ставлення студентів до неї переростає в їхню самоосвітню діяльність. Це відбувається тоді, коли вони усвідомили цілі самостійної роботи й за власним бажанням роблять усе, щоб їх досягти [7, с. 99].

3. Обсяг завдань на самостійну роботу й число контрольних із дисципліни визначаються викладачем або кафедрою, частіше їх дуже багато, що обтяжливо для студента. Не завжди викла- дачем робиться обґрунтована оцінка складності завдання та часу, необхідного на його підготовку.

4. Не узгоджені терміни подання домашніх завдань із різних дисциплін призводять до нерівномірності розподілу самостійної роботи за часом.

5. Багато з пропонованих завдань для студентів не налаштовані на активну роботу, а їх виконання часто може бути здійснено формально, без індивідуального і творчого підходу, а іноді й без розуміння виконуваних завдань.

6. У більшості студентів не сорормована постійна потреба в самоосвіті, самоактуалізації та саморозвитку.

7. Методичне забезпечення самостійної роботи потребує вдосконалення для надання студентам можливості формування власного освітнього шляху.

8. Недостатні навички самостійної роботи студентів блокують зростання професійної компетентності.

Результати опитування дали змогу підсумувати, що організація самостійної роботи студентів - це проблема, яка вимагає ще тривалого дослідження та серйозних підходів. Ефективність її залежить від гнучкого управління, що пов'язане з чітким плануванням, умілою організацією, продуманим методичним забезпеченням, використанням інформаційно-комп'ютерних технологій стосовно самостійної роботи.

Виходячи 3 того, що самостійна робота студентів у сучасних умовах розвитку вищої освіти України $€$ головним резервом підвищення ефективності професійної підготовки викладачів, можна виділили такі фрактори, які сприяють активізації самостійної роботи студентів.

1. Єдині вимоги. Створити єдині вимоги до організації самостійної роботи студентів викладачів з усіх навчальних дисциплін. Визначення обсягів позааудиторної роботи, розроблення нормативів.

2. Постійний контроль. Забезпечити послідовність, систематичність самостійної роботи і зробити самостійну роботу основою стабільного руху студентів шляхом індивідуально-профеесійного самовдосконалення.

Здійснювати керівництво самостійною роботою та контроль за ії ходом.

3. Зрозумілість. Передбачити доступність i посильність навчального матеріалу для самостійного опрацювання студентами.

4. Якісні умови. Забезпечити умови для організації самостійної роботи студентів (наявний аудиторний фронд, відповідна матеріально-технічна база, методичне забезпечення, консультації викладачів тощо).

5. Цінність. Важливо психологічно налаштувати студента, показати йому, наскільки потрібна виконувана ним самостійна робота. 
6. Умотивованість. Використання мотивуючих факторів контролю знань (рейтинг, тести, накопичувальні оцінки, нестандартні екзаменаційні процедури тощо). Ці фрактори можуть викликати прагнення до змагання, що саме по собі $\epsilon$ сильним чинником вмотивованості й самовдосконалення студента.

7. Творчість. Творча наукова діяльність - це основа самостійної роботи. Прикладом такої діяльності може бути залучення студентів до науково-дослідної або методичної роботи, участь в олімпіадах із навчальних дисциплін, конкурсах науково-дослідних робіт, конференціях.

8. Інтегрованість у навчанні. Освіта розглядається через призму загальної картини й не ділиться на окремі дисципліни. Предметні межі зникають, коли викладачі заохочують студентів установлювати зв'язок між дисциплінами й спиратися на знання та навички 3 кількох дисциплін. Розроблення навчальних посібників міждисциплінарного характеру може стати новою сходинкою в самостійній роботі студентів на етапі одержання сучасної освіти.

9. Проблемний підхід. Проблемна ситуація в навчанні - це пізнавальна перепона, для подолання якої студенти мають здобути самостійно нові знання або докласти інтелектуальних зусиль. У подальшому студенти самостійно формулюють проблему та розв'язують її (в курсовій чи дипломній роботі) під контролем викладача.

10. Технологія концентрованого навчання. Ця технологія $€$ інтерпретацією широковідомого методу занурення - навчання 3 елементами релаксації, навіювання і гри. Різновидом цього виду занять $€$ проведення багатогодинного практичного заняття, яке охоплює кілька тем курсу та спрямоване на вирішення наскрізних завдань.

11. Студент-консультант. Призначення студентів-консультантів із найбільш обдарованих студентів і надання їм усебічної допомоги. Практикувати обмін ролями таких студентів із викладачем. Наприклад, читання ними фрагменту лекції за умови їх попередньої підготовки викладачем.

Отже, для успішної організації та фрункціонування самостійної роботи студентів вкрай необхідні, по-перше, комплексний підхід до організа- ції такої роботи за різними фрормами аудиторної роботи, по-друге, поєднання всіх типів самостійної роботи, по-третє, забезпечення якісного контролю за виконанням завдань. На підставі проведеного дослідження та практичного досвіду можна зробити висновок, що вдосконалення педагогічної майстерності викладача вищої школи щодо організації самостійної роботи має відбуватися шляхом системного підходу.

Отже, лише за умови систематичного, планомірного й інтегрованого підходу до організації, проведення, керівництва та управління самостійною роботою можна підготувати висококваліфікованого й компетентного спеціаліста на рівні європейських вимог до профресійної підготовки з достатнім і високим інтелектуальним потенціалом, фраховими і творчими здібностями.

\section{БІБЛІОГРАФІЧНИЙ СПИСОК:}

1. Вища освіта України і Болонський процес : навчальний посібник / за ред. В.Г. Кременя. Тернопіль : Навчальна книга-Богдан, 2004. 384 с.

2. Корнещук В. Самостійна робота студентів як важливий фрактор неперервної профресійної підготовки фрахівців. Збірник наукових праць / Національна академія Державної прикордонної служби України ім. Б. Хмельницького. Хмельницький, 2009. № 48. Ч. 2 (2). С. 71-73.

3. Кочина Л., Сіндіч І. Організація та зміст самостійної роботи студентів. Початкова освіта. 2009. № 11. C. 20-22.

4. Петрук В.А. Теоретико-методичні засади формування профресійної компетентності майбутніх фохівців технічних спеціальностей у процесі вивчення фундаментальних дисциплін : монографрія. Вінниця : УНІВЕРСУМ-Вінниця, 2006. 292 с.

5. Швець Д.Є., Швець Є.Я. Керованість самостійною роботою студентів як шлях для підвищення якості освіти. Гуманітарний вісник ЗДІА. 2010. Вип. 41. С. 203-207.

6. Шевчук С.В., Клименко І.В. Українська мова за профеесійним спрямуванням : підручник. Київ : Алерта, 2010. 696 c.

7. Яковець Н.І., Аніщенко О.В., Дубровська Л.О. Вступ до спеціальності : навчально-методичний посібник для студентів педагогічних спеціальностей / за заг. ред. Н.І. Яковець. 2-ге вид. Ніжин : Видавництво НДУ ім. М. Гоголя, 2006. 167 с. 